\title{
ASUHAN KEBIDANAN CONTINUITY OF CARE PADA NY "A" USIA 24 TAHUN GIP0000 DARI MASA KEHAMILAN HINGGA MASA NIFAS DI PMB ANY ISWAHYUNI, SURABAYA
}

\author{
Shinta Wurdiana ${ }^{1,}$ Elvina Leberina ${ }^{2}$ \\ ${ }^{1,2}$ Prodi DIII Kebidanan, STIKES William Booth Surabaya \\ Email :shintawurdiana24@gmail.com
}

\begin{abstract}
ABSTRAK
Angka kematian ibu (AKI) dan angka kematian bayi (AKB) menjadi salah satu indikator penting dari derajat kesehatan masyarakat. COC. Untuk mencegah atau mengurangi AKI dan AKB tenaga kesehatan memberikan pelayanan kesehatan yang berkualitas secara COC.Tujuan tugas akhir ini adalah menerapkan asuhan kebidanan komprehensif secara Continuity Of Care pada Ny.A di PMB Any Iswahyuni Surabaya Pendekatan yang dilakukan secara diskriptif dimana peneliti mengumpulkan data dan mendiskripsikan proses asuhan kebidanan secara komprehensif dengan anamnesa dan observasi kepada ibu hamil trimester III, bersalin, nifas, bayi baru lahir, dan keluarga berencana dan didokumentasikan dengan model SOAP yaitu pengumpulan data subjektif, objektif, assessment serta penatalaksanaan. Hasil penelitian dilakukan pendampingan secara $C O C$ di PMB Listiani baik secara langsung maupun telemedicine dari tanggal 03 Januari 2021 sampai dengan 8 Maret 2021 Asuhan kebidanan Ny.A pada kehamilan, proses persalinan, nifas, bayi baru lahir, dan keluarga berencana tidak ditemukan kesenjangan antara teori dan kasus. Kesimpulan dari penelitian ini adalah sebagai tenaga kesehatan bidan dapat menenerapkan asuhan kebidanan secara $C O C$ dalam meningkatkan kualitas pelayanan yang membutuhkan hubungan terus menerus antara pasien dan tenaga kesehatan, yaitu memantau kondisi ibu hamil mulai dari awal kehamilan sampai proses persalinan ke tenaga kesehatan, pemantauan bayi baru lahir dari tanda infeksi, komplikasi pasca lahir serta fasilitator untuk pasangan usia subur dalam pelayanan keluarga berencana.
\end{abstract}

Kata kunci : Asuhan Kebidanan, Continuity of Care.

\begin{abstract}
Maternal mortality rate (MMR) and infant mortality rate (IMR) are important indicators of public health status. COC. To prevent or reduce MMR and IMR, health workers provide quality health services in a COC manner. The purpose of this final project is to apply comprehensive midwifery care in a Continuity Of Care manner to Mrs. A at PMB Any Iswahyuni Surabaya. The approach is descriptive in which researchers collect data and describe the process of comprehensive midwifery care with anamnesis and observations to pregnant women in the third trimester, maternity, postpartum, newborn, and family planning and documented with the SOAP model, namely subjective, objective data collection, assessment and management. The results of the study carried out COC assistance at PMB Listiani both directly and telemedicine from January 3, 2021 to March 8, 2021. Mrs. A's midwifery care in pregnancy, childbirth, postpartum, newborn, and family planning did not find any gaps between theory and case. The conclusion of this study is that as health workers, midwives can apply COC midwifery care in improving the quality of
\end{abstract}


services that require continuous relationships between patients and health workers, namely monitoring the condition of pregnant women from early pregnancy to the delivery process to health workers, monitoring newborns. from signs of infection, postnatal complications as well as facilitators for couples of childbearing age in family planning services.

Keyword: Midwifery Care, Continuity of Care

\section{PENDAHULUAN}

Kehamilan dan kelahiran merupakan suatu hal yang fisiologis, namun jika tidak berlangsung dengan baik dan sesuai dengan standar yang ada maka akan menjadi patologis. Pada saat ini AKI Nasional sebesar 305 per 100.000 kelahiran hidup, (Supas,2016). Pada tahun 2019, AKI Provinsi Jawa Timur mencapai 89,81 per 100.000 kelahiran hidup. Angka ini menurun dibandingkan tahun 2018 yang mencapai 91,45 per 100.000 kelahiran hidup. penyebab tertinggi kematian ibu pada tahun 2019 adalah Pre Eklamsi /Eklamsi yaitu sebesar $31,15 \%$ (162 orang) dan perdarahan yaitu $24,23 \%$, penyebab lain-lain yaitu $23,1 \%$ (120 orang). Penyebab lain-lain turun dikarenakan sebagian masuk kriteria penyebab gangguan metabolisme, dan sebagiannya lagi masuk kriteria gannguan peredaran darah. Sedangkan penyebab infeksi meningkat dari tahun 2018 yaitu 6,73\% (35 orang). Tahun 2019 Angka Kematian Bayi (AKB) pada posisi 23 per 1.000 kelahiran hidup (angka estimasi dari BPS Pusat), Angka Kematian Bayi Jawa Timur sampai dengan tahun 2019 sudah di bawah target Nasional. Proporsi kematian bayi masih banyak (3/4) terjadi pada periode neonatal $(0-28$ hari) dan ini terjadi pada setiap tahunnya, bahwa mulai tahun 2015 sampai dengan tahun 2019 ada kecenderungan Angka Kematian Bayi (AKB) stagnan. Sedangkan di Surabaya sendiri pada tahun 2018, AKI kota Surabaya mencapai 72,99 per 100.000 kelahiran hidup. Angka ini mengalami penurunan dibandingkan tahun 2017 yang mencapai 79,40 per 100.000 kelahiran hidup. Penyebab tertinggi kematian ibu pada tahun 2018 adalah penyebab lain-lain yaitu $48,39 \%$, pre eklampsia/eklampsia sebesar 32,26\%, dan perdarahan sebesar $16,13 \%$.

Sebagai tolak ukur yang digunakan untuk mewujudkan menekan AKI yaitu meliputi cakupan K1 dan K4. Untuk cakupan K1 di Surabya 100,09\% sedangkan cakupan K4 di Surabya 98,98\% dari 46.712 ibu hamil. Cakupan kunjungan bayi kota Surabaya pada tahun 2018mencapai 97,78\% dan ada 6 Puskesmas tidak mencapai target yang ditentukan dalam Renstra(90\%). Angka cakupan kunjungan bayi tertinggi pada tahun 2018 terdapat pada Puskesmas Pegirian dengan angka 107,24\% dan yang terendah terdapat pada Puskesmas Pacarkeling dengan angka 48,62\%. Adanya kesenjangan antara cakupan K1 dan K4 dapat diartikan masih banyaknya ibu hamil yang telah melakukan kunjungan pertama pelayanan antenatal tetapi tidak meneruskan hingga kunjungan ke-4 pada triwulan ke tiga sehingga kehamilan terlepas dari pemantauan petugas kesehatan. Kondisi tersebut dapat mengakibatkan kematian pada ibu dan bayi. Salah satu upaya penurunan Angka Kematian Ibu dan Angka Kematian Bayi adalah Program Perencanaan Persalinan dan Pencegahan Komplikasi (P4K). Program dengan menggunakan stiker ini, dapat meningkatkan peran aktif suami (suami Siaga), keluarga dan masyarakat dalam merencanakan persalinan yang aman. Program ini juga meningkatkan persiapan menghadapi komplikasi pada saat kehamilan, termasuk perencanaan pemakaian alat/ obat kontrasepsi pasca persalinan. Selain itu, program $\mathrm{P} 4 \mathrm{~K}$ juga mendorong ibu hamil untuk memeriksakan kehamilan, bersalin, pemeriksaan nifas dan bayi yang dilahirkan 
oleh tenaga kesehatan terampil termasuk skrining status imunisasi tetanus lengkap pada setiap ibu hamil. Kaum ibu juga didorong untuk melakukan inisiasi menyusu dini (IMD) dilanjutkan pemberian ASI eksklusif selama 6 bulan dan Bantua Operasional Kesehatan (BOK) ke puskesmas di kabupaten/kota; safe motherhood initiative, program yang memastikan semua perempuan mendapatkan perawatan yang dibutuhkan sehingga selamat dan sehat selama kehamilan dan persalinannya (tahun 1990); dan Gerakan Sayang Ibu pada tahun 1996 (Mi’raj, 2017).

Upaya peningkatan kesehatan ibu dan penurunan angka kematian ibu mustahil dapat dilakukan sendiri oleh Pemerintah, terlebih dengan berbagai keterbatasan sumber daya yang dimiliki - tenaga, sarana prasarana, dan anggaran. Oleh karena itu, mutlak diperlukan kerja sama lintas program dan lintas sektor terkait, yaitu pemerintah daerah, sektor swasta, organisasi profesi kesehatan, kalangan akademisi, serta lembaga dan organisasi kemasyarakatan baik dari dalam negeri maupun luar negeri. Oleh karena itu untuk membantu upaya percepatan penurunan AKI salah satunya adalah melaksanakan asuhan secara berkelanjutan atau Continuity of Care. Continuity of Care adalah pelayanan yang dicapai ketika terjalin hubungan yang terus menerus antara seorang wanita dan bidan. Asuhan yang berkelanjutan berkaitan dengan tenaga professional kesehatan, pelayanan kebidanan dilakukan mulai awal kehamilan trimester III,persalinan,masa nifas dan bayi baru lahir serta keluarga berencana (Nurwiandani, 2017). Berdasarkan latar belakang tersebut maka penulis tertarik melakukan asuhan kebidanan komprehensif mulai dari masa kehamilan, masa persalinan, masa nifas,perawatan bayi baru lahir serta melakukan pendokumentasian kebidanan yang telah dilakukan pada ibu hamil, bersalin, nifas, dan bayi baru lahir di PMB Any Iswahyuni, Surabaya.

\section{BAHAN DAN METODE}

Penelitian ini menggunakan metode diskriptip dengan pendekatan studi kasus. Dilakukan di PMB Any Iswahyuni, Surabaya, mulai tanggal 3 Januari 2021 sampai dengan 8 Maret 2021 Sampel penelitian yaitu Ny.A usia 24 tahun dengan GIP0 dari masa kehamlan hingga masa nifas.

\section{HASIL PENELITIAN}

1. Setelah dilakukan Contuinity of Care pada Ny.A mulai dari asuhan kehamilan, asuhan persalinan, asuhan bayi baru dan neonatal, asuhan nifas, sampai dengan ibu mengikuti program KB, semua berjalan sesuai dengan harapan, ibu dan bayi sehat dan selamat, komplikasi dapat teratasi.

2. Asuhan kebidanan kehamilan pada Ny.A umur24 tahun dilakukan sebanyak 10 kali kunjungan. Pada penapisan faktor resiko dengan KSPR, didapatkan skor 2, sehingga ibu dikatagorikan kehamilan dengan faktor resiko rendah. Dengan keteraturan kunjungan antenatal care yang dilakukan oleh ibu di PMB Any Iswahyuni, Surabaya berjalan tanpa komplikasi dan terintegrasi.

3. Asuhan kebidanan persalinan Ny.A, ibu melahirkan pada tanggal 25 Januari 2021 jam 13.25 WIB. Proses persalinan kala I berlangsung 7 jam, kala II berlangsung 25 menit, lama kala III 15 menit sedangkan kala IV berlangsung 2 jam post partum. Dengan penatalaksanaan yang adikuat dan sesuai dengan prosedur, proses persalinan Ny.A berlangsung dengan lancar dan aman. 
4. Asuhan kebidanan nifas Ny.A, dilakukan kunjungan sebanyak 2 kali dan 2 kali secara virtual. Selama kunjungan nifas, keluhan ibu nyeri luka jahitan hingga skala 5-6. Hal ini sudah diatasi dengan memberikan terapi asam mefenamat $500 \mathrm{mg} 3 \times 1 /$ hari serta Amoxilin 500mg 3x1/hari. Selain itu ibu dianjurkan menjaga personal hygine terutama di daerah genetalia dengan mencebok dengan sabun tiap kali BAB dan BAK dan mengelap sampai kering dengan tissue atau handuk bersih. Ibu juga dianjurkan tentap mengkonsumsi makanan dengan iet TKTP, hal ini bermanfaat untuk memperbanyak produksi ASI serta mempercepat pemulihan kesehatan ibu pasca persalinan seperti luka episiotomy cepat sembuh. Teknik relaksasi dan distraksi juga diajarkan kepada Ny. A agar nyeri dapat berkurang. . Bidan memberikan konseling tentang pentingnya menjaga kebersihan perinium dan mengkonsumsi makanan tinggi kalori dan tinggi protein.

5. Asuhan kebidanan bayi baru lahir Ny.A, dilakukan kunjungan sebanyak 2 kali dan 2 kali secara virtual. Bayi lahir tanggal 25 Januari 2021 pukul 13.25 WIB. APGAR skor 8-9 BBL 3410 gram PB $50 \mathrm{~cm}$. Asuhan yang diberikan pada bayi baru lahir sampai dengan neonatal telah sesuai dengan standar pelayanan. Bayi mendapatkan cukup nutrisi yaitu ASI saja, sehingga tidak mengalami penurunan berat badan melebihi normal. Bayi juga tidak mengalami ikterus neonatorum. Tanda-tanda vital dalam batas normal, eliminasi lancar, dan bayi menyusu kuat.

6. Asuhan kebidanan keluarga berencana, dilakukan 1 kali bersamaan dengan asuhan masa nifas ke-3 secara virtual dan ke-4 pada tanggal 8 Maret 2021 di PMB
Any. Pada kunjungan KB pertama, Ny. A diberikan konseling tentang manfaat keluarga berencana, jenis alat kontrasepsi, cara kerja, dan efek samping dengan menggunakan bahasa yang mudah dipahami oleh ibu, sehingga pada 40 hari postpartum Ibu dan keluarga sudah memutuskan menjadi akseptor KB suntik 3 bulan.

\section{PEMBAHASAN}

\section{Asuhan Kebidanan pada Ibu Hamil Trimester II dan III}

Dalam pembahasan yang berkaitan dengan Antenatal Care maka, dapat diperoleh data bahwa Ny.A usia 24 tahun mengatakan hamil ke 1, HPHT 25-04-2020 TP 30-01-2021 dan dalam anamnesa tidak di temui kesenjangan, keluhan yang dirasa saat itu sering kencing. Sedikit nyeri pada pinggang, dan susah tidur, Ini merupakan kunjungan kehamilan ke 8 . Sesuai dengan teori Kemenkes (2016) bahwa umur Ny. "A" termasuk usia yang baik untuk reproduksi. Jadwal control Ny A juga sudah lebih dari standar yang telah ditentukan, apalagi mengingat di era pandemic covid 19 ini harusnya ada perlakukan khusus tentang standar pemeriksaan kehamilan yaitu Kunjungan wajib pertama dilakukan pada trimester 1 direkomendasikan oleh dokter untuk dilakukan skrining faktor risiko (HIV, sifilis, Hepatitis B). Jika kunjungan pertama ke bidan, maka setelah ANC dilakukan maka ibu hamil kemudian diberi rujukan untuk pemeriksaan oleh dokter.Kunjungan wajib kedua dilakukan pada trimester 3 (satu bulan sebelum taksiran persalinan) harus oleh dokter untuk persiapan persalinan, menurut Kemenkes (2020). Jika dilihat dari usia kehamilan 3738 minggu, Ny. "A" mengeluh sering kencing, nyeri pinggang, dan susah tidur . Menurut penulis selama kehamilan III sering terjadi ketidaknyamanan seperti 
sering kencing, sering kencing dirasakan pada III karena semakin besar uterus maka akan menekan bagian kendung kencing, juga karena hormone estrogen dan progesterone semakin meningkat. Hal ini sesuai dengan teori Walyani(2015) Ketidaknyamanan yang sering terjadi selama masa kehamilan trimester II dan III adalah sering kencing, sakit kepala, bengkak pada kaki, kram pada kaki dan nyeri punggung, Nyeri punggung ini biasanya akan meningkat intensitasnya seiring bertambahnya usia kehamilan karena nyeri ini merupakan akibat pergeseran pusat gravitasi wanita dan postur tubuhnya. Berdasarkan hal di atas keadaan fisik Ny.'A' masih dalam keadaan normal. Kehamilan berjalan dengan fisiologis.

Untuk pemeriksaan fisik yang telah dilakukan keadaan umum dalam batas normal. Sesuia diagnose yang telah ditegakkan Ny.A Uk 36-37minggu Saat dilakaukan pemeriksaan leopold ukuran TFU Ny."A" termasuk fisiologis, perubahan atau ukuran TFU setiap ibu memang berbeda sesuai dengan bentuk perut dan ketebalan dinding perut namun dengan rumus yang sudah ada dapat dengan mudah mengukur TFU ibu hamil. Menurut Walyani (2015), usia kehamilan 36-37 minggu : fundus uteri terletak kira-kira 3 jari. Berdasarkan hal di atas maka pemeriksaan TFU Ny. "A" masih dalam batas normal. Pemeriksaan fisik lainya pada Ny. "A'" dalam batas normal.

Pemeriksaan Penunjang yang telah dilakukan $\mathrm{Ny}$ " $\mathrm{A}$ " adalah pemeriksaan $\mathrm{Hb}$ yaitu sebebsar $11,8 \mathrm{gr} \%$. Menurut penulis, haemoglobin sangat berpengaruh langsung terhadap ibu dan janin karena untuk mengetahui jumlah sel darah merah ibu hamil, agar kadar haemoglobin stabil ibu dapat beristirahat dengan waktu yang cukup, serta mengkonsumsi makanan yang bergizi, kadar haemoglobin yang rendah pada ibu hamil dapat menyebabkan anemia yang berdampak bagi ibu dan bayi bisa terjadi perdarahan pada nifas, dan BBLR. Menurut Roumali (2014), kadar Hb normal 11-14gr\%. Berdasarkan hal diatas kadar haemoglobin Ny. "A" masih dalam batas normal. Pemeriksaan urine albumin dan reduksi sesuai data yang diperoleh $\mathrm{Ny}$." $\mathrm{A}$ " adalah negatif. Menurut penulis hal ini fisiologis karena pada ibu hamil sebaiknya urine albumin dan reduksi hasilnya negatif, karena jika hasilnya positif dapat menjadi masalah pada kesehatan seperti bisa menyebabkan terjadinya komplikasi kehamilan seperi DMG dan preeklampsia yang akan menyebabkan kejang pada masa kehamilan, perdarahan pada masa nifas, BBLR, bahkan bisa menyebabkan kematian pada ibu. Menurut Roumali (2014), pemeriksaan urine albumin normal bila hasilnya negatif (urine tidak keruh).

Berdasarkan fakta analisa data pada Ny."A" adalah G1P0A0 usia kehamilan 37 minggu dengan hehamilan normal. Menurut penulis, dalam memberikan asuhan pada Ny. "A" kehamilan berjalan normal tidak mengalami komplikasi atau, keadaan ibu dan janin sehat tidak ada gangguan. Pada kehamilan 26-30 minggu ibu sering mengeluh sering kencing. Menurut Walyani (2015) keluhan kehamilan pada trimester III terjadi pembesaran janin yang juga menyebabkan desakan pada kantung kemih. Tindakan mengurangi asupan cairan untuk mengurangi keluhan ini tidak dianjurkan, karena akan menyebabkan dehidrasi karena iu merupakan hal yang fisiologis.

Asuhan pada masa hamil penulis melakukan penatalaksanaan pada Ny."A" sebagaimana asuhan yang diberikan untuk kehamilan normal karena tidak ditemukannya masalah, asuhan yang diberikan yaitu seperti KIE tentang tanda bahaya ibu hamil, tanda-tanda persalinan, persiapan persalinan, keluhan pada ibu 
hamil seperti kenceng-kenceng, dan sebagainya, kolaborasi pemberian suplemen, dan kontrol ulang. Menurut penulis hal ini fisiologis.Menurut Walyani (2015), asuhan yang diberikan untuk kehamilan normal karena diantaranya KIE tentang keluhan pada ibu hamil seperti kenceng-kenceng, dan sebagainya, tanda bahaya ibu hamil, tanda-tanda persalinan, persiapan persalinan, kolaborasi pemberian suplemen, dan kontrol ulang.Berdasarkan hal diatas, penatalaksanaan kehamilan $\mathrm{Ny}$ " $A$ " sudah sesuai dengan keluhan yang di alami.

\section{Asuhan Kebidanan pada Ibu Bersalin}

Pemeriksaan pada Intra Natal Care yang dilakukan oleh Ny "A" dengan persalinan normal di PMB Any Iswahyuni, Amd.Keb, dalam anamnesa tidak di temui kesenjangan, keluhan yang dirasa saat itu Ibu mengatakan kenceng-kenceng dan keluar lendir dari jalan lahir sejak pukul $09.00 \mathrm{WIB}$, tiap 15 menit sekali.

Menurut Manuaba (2015) keluhan yang sering dirasakan ibu bersalin yaitu dimulai dengan adanya his yang dipengaruhi oleh hormon esterogendan progesterone. Selanjutnya keluar lendir darah terjadi karena adanya pembuluh darah yang pecah akibat pendataran dan pembukaan servik. Adanya pengeluaran cairan, hal ini dikarenakan karena ketuban pecah. Sebagian ketuban pecah menjelang pembukaan lengkap. Dengan pecahnya ketuban diharapkan persalinan berlangsung dalam waktu 24 jam. Menurut penulis proses persalinan pada ibu yang hamil cukup bulan, dengan presentasi belakang kepala, yang berlangsung dalam waktu 24 jam dan tidak menimbulkan komplikasi baik ibu maupun janin. Yang diawali dengan terjadinya kontraksi/mules yang datang teratur setiap 10-15 menit,keluarnya lendir dan darah dari jalan lahir dengan 4 tahapan yaitu kala 1, kala 2, kala 3 dan kala 4. Berdasarkan hal diatas keadaan fisik Ny. "A" masih dalam keadaan normal. Persalinan berjalan dengan fisiolongis.

Berdasarkan fakta, persalinan kala I fase laten $\mathrm{Ny}$. " $\mathrm{A}$ " berlangsung selama 3 jam 40 menit (09.00-12..40WIB). Pada kala ini pasien mendapatkan asuhan pemenuhan nutrisi, mobilisasi dan relaksasi.Menurut penulis hal ini fisiologis, merupakan kemajuan persalinan yang bagus bahwa batas pembukaan persalinan yaitu primigravida 10 12 jam dan multigravida 8-10 jam dan telah mendapatkan asuhan yang sesuai. Menurut Sulistiyowati (2013) persalinan kala I berlangsung antara pembukaan $0-10 \mathrm{~cm}$. Pada permulaan His, kala pembukaan berlangsung tidak begitu kuat sehingga pasien masih dapat berjalan-jalan. Lamanya kala 1 untuk primigravida sekitar 12 jam sedangkan multigravida sekitar 8 jam. Berdasarkan kurva friedman, diperhitungkan pembukaan primigravida $1 \mathrm{~cm} / \mathrm{jam}$ dan pembukaan multigravida $2 \mathrm{~cm} / \mathrm{jam}$.Pada partograf Ny. "A" tidak melewati garis waspada, ibu diberikan makan dan minum dan tehnik relaksasi, hal ini sesuai dengan pendapat Sarwono (2015), pada ibu bersalin kekuatan dipengaruhi asupan nutrisi sebelum persalinan. Berdasarkan hal diatas tidak ada kesenjangan antara teori, opini denfakta.Dengan penatalaksanaan KIE nutrisi, mengajari mobilisasi dan relaksasi.

Berdasarkan fakta, persalinan kala II Ny. "A" berlangsung selama 15 menit (17.55 WIB), tidak ada penyulit selama proses persalinan pasien mendapatakan asuhan bimbingan meneran, pertolongan persalinan dan IMD. Menurut penulis hal ini fisiologis karena partograf tidak melewati garis waspada. menurut Sulistiyowati (2013), Kala I dimulai dari pembukaan lengkap $(10 \mathrm{~cm})$ sampai bayi lahir. Proses ini berlangsung 2 jam pada primigravida, dan pada multigravida1jam. Menurut (APN, 2016) pada kala II diberikan asuhan bimbingan meneran, pertolongan persalinan dan IMD 
untuk mempercepat berlangsungnya proses persalinan.

Berdasarkan fakta, persalinan kala III Ny."A" berlangsung selama 10 menit (17.30 WIB), tidak ada penyulit pasien mendapatakan asuhan penyuntikan oksitosin, PTT, dan masasse.Menurut penulis hal ini fisiologis dalam kala III karena tidak ada penyulit atau masalah yang menyertai,menurut Sulistiyowati (2015), kala III dimulai segera setelah bayi lahir sampai lahirnya plasenta, yang berlangsung tidak lebih dari 30 menit secara Duncan (dimulai dengan adanya semburan darah) dengan asuhan menejemen aktif kala III. Berdasarkan hal diatas, tidak dijumpai kesenjangan antara fakta, opini dan teori. Dengan penatalaksanaan penyuntikan oksitosin, PTT, dan masasse. Persalinan kala IV Ny."A " berlangsung selama2 jam pertama (19.30 WIB), perdarahan $20 \mathrm{cc}$, kandung kemih kosong. Pasien mendapatkan asuhan pemeriksaan TTV, masasse dan personal hygiene. Menurut penulis hal ini fisiologis perdarahan dan TTV dalam batas normal tidak melebihi batas maksimal pasien telah mendapat asuhan yang sesuai. Hal ini sesuai dengan teori Jannah (2017), kala IV dimulai dari saat lahirnya plasenta sampai 2 jam pertama post partum. Observasi yang harus dilakukan pada kala IV adalah : tingkat kesadaran klien, periksaan tanda-tanda vital : tekanan darah, nadi, dan pernapasan, kontraksi uterus, TFU, terjadinya perdarahan, perdarahan dianggap masih normal jika jumlahnya tidak melebihi 400-500 cc.Berdasarkan hal diatas, tidak ditemui adanya kesenjangan antara fakta, opinidan teori.Dengan penataksanaan observasi TTV, masasse dan personal hygiene.

\section{Asuhan Kebidanan pada Ibu Nifas}

Pada pemeriksaan Postnatal Care yang dilakukan oleh $\mathrm{Ny}$ "A" tergolong dalam masa nifas normal. Pada 7 jam post partum ibu mengeluh mules dan nyeri luka jahitan.
Menurut penulis mulesa dalah keadaan fisiologis karena proses kembalinya alat-alat reproduksi ke bentuk semula, sehingga uterus berkontraksi dan menyebabkan rasa mules. Pada 7 jam post partum ibu biasanya masih mengeluh nyeri pada luka bekas jahitan dikarenakan jahitan masih basah dan ibu belum bisa bergerak dengan bebas, maka dianjurkan kepada ibu untuk melakukan mobilisasi dini. Keadaan ibu yang baik selama masa nifas dipengaruhi oleh nutrisi, ibu makan makanan yang bergizi seperti nasi, lauk pauk, sayur, dan minum air putih 7 gelas setiap hari, ibu juga tidak tarak terhadap makanan apapun. Pulihnya keadaan ibu juga dipengaruhi oleh aktifitas ibu setiap harinya seperti menyapu, merawat anak. Menurut Rukiyah (2015). Masa nifas adalah masa setelah keluarnya plasenta sampai alat-alat reproduksi pulih seperti sebelum hamil dan secara normal masa nifas berlangsung selama 6 minggu atau 40 hari. Berdasarkan hal diatas keluhan Ny. "A" masih normal. Berdasarkan fakta, ASI Ny "A" sudah keluar lancar, tidak ada bendungan, tidak ada massa abnormal. Menurut penulis hal ini fisiologis pada payudara terjadi proses laktasi. Pada keadaan fisiologis, tidak terdapat benjolan, pembesaran kelenjar atau abses. Menurut Sulistyowati, (2015) ASI matur dikeluarkan mulai hari ke 14 post partum, keluarnya ASI dengan lancar dapat dipengaruhi oleh refleks hisap bayi/ refleks let down, semakin kuat hisapan bayi, semakin lancar ASI yang keluar. Berdasarkan hal diatas, proses laktasi Ny. "'A' berjalan normal.

Kontraksi uterus Ny."Y" sangat baik sehigga involusi uterus berjalan normal dan cepat yaitu 4 minggu TFU sudah tidak teraba. Menurut Marmi (2015), TFU menurut masa involusi bayi lahir setinggi pusat, plasenta lahir 2 jari dibawah pusat, 1 minggu pertengahan pusat symphisis, 2 minggu tidak teraba diatas symphisis, 6 minggu bertambah kecil, 8 minggu sebesar normal (tidak teraba).Berdasarkan hal diatas ukuran TFU 
Ny. "A' masih dalam batas normal, nifas berjalan dengan fisiolongis. proses involusi berdasarkan lochea pada Ny. "A" berjalan fisiologis, pada 3 hari post partum lochea sanguilenta, pada 14 hari post partum lochea serosa, pada 30 hri post partum lochea alba.Menurut peneliti.Menurut Walyani, dkk (2015), bahwa lochea rubra berwarna merah berlangsung selama 1-2 hari post partum, lochea sanguinolenta warnanya merah kuning berisi darah dan lendir, terjadi pada hari ke 3-7 hari post partum, lochea serosa berwarna kuning dan cairan ini tidak berdarah lagi pada hari ke 7-14 post partum, lochea alba merupakan cairan putih yang terjadi pada hari setelah 2 minggu post partum.

Penatalaksanaan asuhan kebidanan ibu nifas pada Ny"A" sebagaimana untuk ibu nifas normal karena tidak ditemukannya masalah, seperti melakukan observasi pengeluaran pervaginam, tinggi fundus uteri, dan proses laktasi, memberikan KIE tentang tanda bahaya nifas, ASI eksklusif, nutrisi, dsb, dan kontrol ulang. Menurut penulis, dengan diberikan implementasi yang sesuai dengan asuhan pada ibu nifas dapat mencegah terjadinya tanda bahaya masa nifas seperti demam, perdarahan, lokhea berbau, bendungan ASI, dsb. Selain itu juga memberikan dampak yang postif bagi ibu dan bayi seperti mengajari ibu bagaimana cara menyusui yang benar, melakukan perawatan bayi sehari-hari, memberikan konseling tentang $\mathrm{KB}$ agar ibu merasa mantap dan nyaman sebelum menggunakan alat kontrasepsi.

\section{Asuhan Kebidanan pada Neonatus}

Dalam pembahasan ke-empat yaitu tentang bayi baru lahir Ny.Y dengan data berikut yaitu usia 5 jam masa transisi, sudah BAB warna hitam (Mekonium), BB lahir 3.410 gr, PB $50 \mathrm{~cm}$, warna kulit merah muda, bayi sudah dilakukan IMD, reflek pada bayi baik dan dalam anamnesa dengan ibu tidak di temui kesenjangan, tidak ada keluhan. Ini merupakan kunjungan masa neonatus ke 1 . Pemeriksaan fisik pada neonatus sangat penting karena dengan melakukan pemeriksaan kita bisa menyimpulkan resiko atau komplikasi yang menyertai, selain itu bisa mencegah terjadinya tanda bahaya bayi, bayi yang mengalami kelainan dapat disebabkan karena kurangnya nutrisi yang dikonsumsi ibu. Menurut Walyani (2015) warna kulit bayi harus berwarna merah muda yang bersih, tidak ada kelainan pada anggota tubuh, dan tidak ada tanda-tanda infeksi tali pusat. Berdasarkan hal diatas pemeriksaan fisik pada bayi Ny. "A" masih dalam batas normal. penatalaksanaan pada Bayi Ny "A" sebagaimana untuk neonatus normalkarena tidak ditemukan masalah selama kunjungan. Asuhan yang diberikan yaitu memberikan KIE, seperti KIE tanda bahaya neonatus, imunisasi, ASI eksklusif, perawatan bayi sehari-hari dsb. KIE diberikan secara bertahap agar ibu lebih mudah dalam memahami penjelasan yang diberikan, imunisasi, kontrol ulang.Menurut Walyani(2015) penatalaksanaan pada neonatus fisiologis, meliputi KIE tanda bahaya neonatus, imunisasi, ASI eksklusif, perawatan bayi sehari-hari dsb. KIE diberikan secara bertahap agar ibu lebih mudah dalam memahami penjelasan yang diberikan, imunisasi, dan kontrol ulang. Berdasarkan hal diatas penatalaksanaan bayi pada Ny. "A'" sudah sesuai dengan asuhan neonatus.

\section{Asuhan Kebidanan pada Keluarga Berencana}

Pembahasan yang kelima adalah tentang asuhan kebidanan keluarga berencana yang dilakukan oleh Ny "A" usia 24 tahun dengan akseptor baru KB suntik 3 bulan. Berikut akan disajikan data-data yang mendukung untuk dibahas dalam pembahasan tentang asuhan kebidanan keluarga berencana. Dalam pembahasan 
yang berkaitan dengan asuhan kebidanan keluarga berencana maka, dapat diperoleh data bahwa Ny. A usia 24 tahun mengatakan baru menggunakan $\mathrm{KB}$ setelah persalinan, hasil pemeriksaan ibu dalam batas normal salah satunya tekanan darah ibu yaitu 110/70 $\mathrm{mmHg}$ dalam anamnesa tidak di temui kesenjangan, alasan kunjungan ibu ingin menggunakan $\mathrm{KB}$

Keadaan ibu dalam batas normal semua, serta rencana ibu untuk memilih $\mathrm{KB}$ suntik 3 bulan adalah hal yang efektif karena ibu tidak mau menggunakan KB jangka panjang dan juga KB suntik 3 bulan tidak memengaruhi produksi ASI. Menurut Affandi (2015), yaitu kontrasepsi suntikan progestin cocok untuk ibu menyusui, boleh digunakan oleh wanita pada tekanan darah $<180 / 110 \mathrm{mmHg}$, usia reproduksi, nulipara dan yang telah memiliki anak, menyusui dan membutuhkan kontrasepsi yang sesuai, tidak dapat menggunakan kontrasepsi yang mengandung estrogen, sering lupa menggunkan pil kontarsepsi, yang tidak boleh menggunakan kontrasepsi suntikan progestin wanita hamil atau dicurigai hamil, perdarahan pervaginam yang belum jelas penyebabnya, tidak dapat menerima terjadinya gangguan haid terutama amenorea, menderita kanker payudara atau riwayat kanker payudara dan diabetus melitus.Berdasarkan hal diatas kontrasepsi yang di pilih Ny. ' A' sudah cocok.

$$
\text { Penatalaksanaan pada Ny."A" }
$$

akseptor baru $\mathrm{KB}$ suntik 3 bulan, ibu diberi KIE tentang efek samping KB suntik 3 bulan, keuntungan dan kerugian KB suntik 3 bulan dan kunjungan ulang. Menurut Affandi (2015) penatalaksanaan pada akseptor baru KB suntik 3 bulan meliputi KIE efek samping, keuntungan dan kerugian KB suntik 3 bulan, tanda bahaya dan kunjungan ulang.berdasarkan hal diatas penatalaksanaan KB Ny." A" sudah sesuai dengan keluhan.

\section{SIMPULAN DAN SARAN Simpulan}

Pelaksanaan asuhan kebidanan secara Continuity of Care pada Ny.A berjalan dengan lancar. Ibu dan bayi dalam keadaan sehat dan normal.

a. Asuhan kebidanan kehamilan Ny. A berjalan dengan baik, dengan asuhan kehamilan adikuat dan terintregrasi, keluhan ibu selama kehamilan dapat diatasi. Ny.A mendapatkan program pelayanan atau asuhan standar minimal 10T

b. Asuhan kebidanan persalinan berlangsung normal dengan 60 langkah APN. Dengan penatalaksanaan yang adikuat ibu tidak mengalami komplikasi dalam persalinan seperti perdarahan.

c. Asuhan kebidanan nifas, keluhan nyeri luka jahitan juga dapat diatasi dengan terapi analgesic dan antibiotic serta KIE yang sesuai dengan keluhan ibu.

d. Asuhan kebidanan bayi baru lahir, bayi mendapatkan cukup asupan gizi dari ASI ibu sehingga berat badan bayi naik dan tidak mengalami ikterus neonatorum.

e. Asuhan kebidanan keluarga berencana, ibu menggunakan metode kontrasepsi injeksi tiga bulan dan tidak mengalami efek samping.

\section{Saran}

Asuhan kebidanan Continuity of Care merupakan asuhan yang komprehensif dan terbukti efektif menurunkan Angka Kematian Ibu dan Bayi. Asuhan pada ibu mulai dari kehamilan sampai dengan keluarga berencana harus dilaksanakan secara adikuat, berkesinambungan dan terintegrasi, dilaksanakan mulai dari tingkat pelayanan kesehatan dasar sampai dengan rumah sakit. Mahasiswa Bidan, Bidan dan tenaga medis serta tenaga paramedis lainnya harus mempunyai komitmen bersama dalam usaha meningkatkan kesehatan ibu dan anak. 


\section{DAFTAR PUSTAKA}

Andina, Diah. 2018. Asuhan Kebidanan

Kehamilan. Yogyakarta: Nuha Medika Utama.

Arinda.2015. Kehamilan,Persalinan \& Gangguan Kehamilan. Jakarta: EGC.

Asrinah\&Sulistyorini, $\quad$ D.2017.Asuhan

Kebidanan Kehamilan.Yogyakarta: Nuha Medika.

Bahiyatun. 2016. Buku Ajar Asuhan Kebidanan Nifas Normal. Jakarta: EGC.

Dinas Kesehatan Jawa Timur.2019. Profil

Kesehatan Jawa Timur 2019.

Dinas Kesehatan Surabya.2018. Profil

Kesehatan Surabaya 2018.

Diana,Sulis.2017. Model Asuhan Kebidanan

Continuity Of Care. Surakarta:

CV Kekata Grup.

Fitriana. Y. \& Nurwiandani. W. 2018.

Asuhan Persalinan. Yogyakarta: Pustaka Baru Press.

Jannah Nurul. 2017. Askeb II Persalinan . Jakarta : EGC.

Jurnal Manajemen Kesehatan Indonesia. 2015.

file:///C:/Users/Windows\%208/Dow

nloads/yang\%20lama/penting\%20buat \%20LTA.\%20mutu\%20pel.anc.pdf.

(diunduh pada tanggal 09 maret 2017). .2015.Buku Ajar Kesehatan Ibu dan

Anak Continium of Carelife Cycle. Jakarta: Pusdinakes. 2015. Profil Kesehatan Indonesia.http://www.depkes.go.id/r esources/download/pusdatin/profilkesehatan-indonesia/profil-

kesehatan-Indonesia-2015.pdf(diunduh pada tanggal 15 Februari 2015). .2015. Panduan Materi Kesehatan

Reproduksi dan Keluarga Berencana. Yogyakarta: Pustaka baru.

Kemenkes RI.. Profil Kesehatan Indonesia tahun 2016. Jakarta

KemenkesRI;2016.

Muslihatun. W. N. Asuhan Neonatus, Bayi dan Balita. Yogyakarta: Fitramaya.
Marmi. 2015. Asuhan Kebidanan Pada Ibu Nifas. Yogyakarta: Pustaka Pelajar.

Marmi. 2016. Intranatal Care. Yogyakarta: Pustaka Pelajar.

Nugroho, T, dkk. (2014). Buku Ajar Askeb1

Kehamilan. Yogyakarta: Nuha

Medika.

Prawirohardjo, S. 2014. Ilmu Kebidanan. Jakarta: Yayasan Bina Pustaka.

Riset Kesehatan Dasar(Riskesdas).

(2013).Badan Penelitian dan

PengembanganKesehatan

Kementerian RI tahun 2013.Diakses: 19 Oktober 2014.

Sulistyawati. 2015. Asuhan Kebidanan Pada

Masa Nifas. Jakarta : Salemba

Medika.

Sulistyawati. 2015.Buku Ajar Asuhan Kebidanan pada Ibu Nifas. Yogyakarta : ANDI

Sutanto, A. V \& Fitriani, Y. 2015. Asuhan

Pada Kehamilan.Yogyakarta: Pustaka Baru Press.

Saifuddin. 2013. Ilmu Kebidanan.Jilid III. Jakarta : Nusa Pustaka.

Saleha, S. 2013. Asuhan Kebidanan Pada Masa Nifas. Jakarta: Salemba Medika.

Setiyaningrum. E. dan Zulfa. B. A, 2014. Pelayanan Keluarga Berencana dan Kesehatan

Reproduksi.Jakarta: Trans Info Media.

Tando, N. M. 2016. Asuhan Kebidanan Neonatus, Bayi Dan Anak Balita. Jakarta: EGC.

Walyani, Elisabeth Siwi. 2015.Asuhan Kebidanan pada kehamilan. Yogyakarta: Pustaka Barupess.

Walyani, S. E. Purwoastuti, E. (2015). Asuhan Kebidanan persalinan \& Bayi Baru Lahir. Yogyakarta: Pustaka Baru perss.

Walyani, S.E \& Purwoastuti, E. (2015) Asuhan Kebidanan Masa Nifas \&Menyusui. Yogyakarta: Pustaka Baru Perss. 
Walyani, S, Elisabeth. (2016). Asuhan Kebidanan Persalinan dan Bayi Baru. Lahir. Yogyakarta: Pustaka Baru Press. 